\title{
ANALISIS PENGARUH VARIABEL SOSIAL EKONOMI MASYARAKAT URBAN TERHADAP KEMANDIRIAN EKONOMI DITINJAU DARI ASPEK KEUANGAN, ENERGI, DAN PANGAN DI KECAMATAN SINGOSARI KABUPATEN MALANG
}

\author{
Supartono \\ Khusnul Ashar \\ Mochamad Affandi \\ Fakultas Ekonomi Universitas Brawijaya
}

\begin{abstract}
This study aims to assess the contribution of local economic independence for the urban community village of Candi Renggo, Singosari District in the short term from the aspects of finance, energy and food; and analyze whether independence was simultaneously able to survive in the long run. The analysis showed that the economic and social resource for the urban community is quite adequate so that resources can be synergy between mutually exclusive and weaknesses. For the people in selected villages have the ability to develop and demonstrate a significant contribution, although the level is still low. The results of this study partially and simultaneously to the combined respondents (agricultural and non agricultural sector) contribution proved adequate, but not yet able to explain in detail the contribution was sufficient for respondents who work in agriculture and non agricultural sector alones.
\end{abstract}

Keywords: local economic independence, urban society.

\section{A. LATAR BELAKANG}

Sejak tekanan ekonomi global 1997 melanda seluruh negeri tanpa kecuali termasuk Indonesia, kiranya pembangunan terus menerus dilaksanakan. Upaya untuk bangkit memang masih banyak menghadapi hambatan. Hambatan dimaksud antara lain penurunan kegiatan sektor pertanian, industry, perdagangan dan jasa. Setelah masa 5 tahun krisis ekonomi terlewati, telah terjadi perubahan perilaku masyarakat yang mendasar serta meningkatnya kesadaran masyarakat untuk bergerak kembali menuju pada struktur ekonomi yang kuat. Disadari bahwa perubahan seperti itu merupakan suatu proses yang kiranya memerlukan waktu yang cukup panjang dengan akselerasi yang sedikit diusahakan lebih cepat. Hal tersebut dicerminkan pada tingkat pertumbuhan ekonomi negative pada masa 5 tahun setelah krisis dan saat ini menunjukkan angka yang positif walaupun masih relatif rendah.

Struktur ekonomi seperti tercantum dalam konstitusi dalam bagian yang lebih sempit lebih berorientasi pada penguatan sumberdaya ekonomi, terlebih pada sumberdaya ekonomi lokal. Sumberdaya yang melimpah memerlukan pengelolaan yang memadai. Pendekatan agregat ter- 
padu sangat diperlukan. Intensitas antar input perlu ditingkatkan. Kombinasi input belum optimal selanjutnya mengakibatkan pencapaian hasil yang kurang optimal pula. Fenomena satu input dengan input yang lain memerlukan tali perekat yang kuat sehingga dapat bersinergi dan saling meniadakan kelemahan diantara hubungan tersebut. Struktur ekonomi yang berorientasi pada sumberdaya seharusnya dilengkapi dengan struktur yang berorientasi pada kebutuhan masyarakat secara agregat (Prawirohardjono, 1992). Ketiga sektor masing-masing primer, sekunder, dan tersier harus dikemas sedemikian rupa sehingga mendatangkan hasil yang tinggi (benefit). Pada gilirannya potensi yang padu diantara potensi produksi, konsumsi, dan distribusi diarahkan pada kemandirian. Kemandirian dalam arti luas, yaitu bagi seluruh sumberdaya dicoba dikelola, dikembangkan sehingga memberikan kontribusi yang memadai (full employment). Tidak mudah memang mencapai seperti perihal diatas, namun selalu dicoba sehingga terhindar dari pemanfaatan sumberdaya yang kurang produktif (under employment).

Penelitian ini dilaksanakan, disamping mengkaji beberapa kontribusi kemandirian ekonomi ditinjau dari aspek keuangan, energy, dan pangan juga mengkaji sampai seberapa kuat peranan ketiga aspek tadi mampu diterjemahkan dalam suatu analisis yang berkaitan dengan tingkat pendapatan responden, pengeluaran serta ketahanan responden untuk senantiasa menjaga kesejahteraannya. Dengan pendekatan kategoris responden, yaitu responden yang bekerja di sektor pertanian dan responden yang bekerja disektor non pertanian di analisis secara sektoral agar mampu menggambarkan secara dimana sektor pertanian tangguh, sektor industry kuat dan sektor produksi jasa mapan yang senantiasa bersifat resources-oriented dilengkapi dengan needs-oriented.

Pembangunan yang dilaksanakan termasuk mencapai kemandiriam ekonomi tidak boleh menguras sumberdaya yang ada, namun justru sebaliknya memperluas dan mengembangkan peranan dari sumberdaya agar tercipta kontribusi masing-masing secara optimal. Studi ini juga mengemukakan data sosial-ekonomi demografis yang perlu ditelaah lebih mendalam mengingat karakter masyarakat urban yang nampak samar.

\section{Kemandirian Ekonomi}

Beberapa studi memperoleh temuan, bahwa kemandirian ekonomi masyarakat sangat dipengaruhi oleh faktor didalam dan faktor diluar dari masyarakat itu sendiri. Dalam jangka panjang sebenarnya kedua faktor di atas lebih pada pendekatan historis, yaitu bahwa sumberdaya yang dimiliki bersifat given, artinya demikian adanya.

Sumberdaya demikian telah ada dan dimiliki begitu rupa sehingga untuk merubah dan mengembangkan amat tergantung pada cara pengelolaannya. Tambahan lagi faktor dari luar akan membantu dalam mengakomodir sehingga dapat dicapai suatu prestasi yang tinggi. Faktor dari dalam (endowment factor) seringkali sudah ada dan dimiliki sesuai dengan karakter lingkungannya, sedangkan faktor di luar (exogeneous) lebih bersifat melengkapi, misalnya aspek teknologi, pasar dan sebagainya. Kemandirian masyarakat juga dipengaruhi oleh potensi sumberdaya, pemanfaatan dan pelestarian sumberdaya sehingga penelitian terapan demikian amat penting. Pada daerah penelitian tersebut dapat dikemukakan keadaan sosial ekonomi sebagai sumberdaya yang (potensial) ada sangat memadai.

Desa Candirenggo merupakan desa terpilih, terletak di tengah-tengah bagian wilayah Kecamatan Singosari Kabupaten Malang. Desa ini benar-benar mencerminkan desa-urban, dimana 
dibatasi dengan desa lain, yaitu Desa Ardimulyo, Desa Pagentan, Desa Gunungrejo, dan Desa Losari. Luas wilayah desa meliputi 338,567 ha. Luas keseluruhan untuk permukiman sebesar 149 ha, tanah swah seluas 35 ha, dan sisanya luas untuk bangunan gedung-gedung kantor dans sebagainya. Tingkat kesuburan tanah tergolong kategori sedang, dengan curah hujan yang cukup (331 mm/tahun). Hasil panen padi dan palawija cukup produktif yaitu padi sekitar 125 ton gabah padi sawah dan 40 ton padi tadah hujan/ ladang dengan luas masing-masing efektif 23 ha dan 10 ha. Hewan peliharaan terdapat : sapi, kerbau, kuda, kambing, dan ayam serta itik. Khusus untuk sapi terdapat 15 ekor sapi perah dan 13 ekor sapi potong serta 15 ekor kerbau.

Jumlah penduduk di desa Candirenggi meliputi 15.335 jiwa (2009). Jumlah keluarga miskin sebesar $524 \mathrm{KK}$. Struktur mata pencaharian penduduk dapat dikemlompokkan menjadi 3, yaitu 629 orang petani, 301 orang bekerja di sektor jasa, dan 4541 orang bekerja di sektor industry. Pada umumnya mereka yang bekerja di sektor jas, ialah pada bidang jasa perdagangan, angkutan, dan keterampilan (tukang kayu, tukang batu, termasuk pula montir, bordir) dimana jasa demikian berkembang cukup baik. Jasa perdagangan, antara lain berupa took, kios, warung. Di desa ini terdapat pula beberapa orang sebagai pegawai negeri (PNS), dokter dan tentara nasional Indonesia (TNI). Dari segi pendidikannya, penduduk di desa ini cukup maju hal ini nampak pada tabel berikut:

Tabel 1. Tingkat Pendidikan Penduduk Desa Candirenggo, Kec. Singosari, 2009

\begin{tabular}{clc}
\hline No & \multicolumn{1}{c}{ Tingkat Pendidikan } & Jumlah \\
\hline 1. & Sekolah Dasar & 655 \\
2. & Sekolah Lanjutan Pertama & 3.497 \\
3. & Sekolah Menengah Atas & 3.115 \\
4. & Strata 1/ Sarjana & 598 \\
5. & Strata 2/ Pasca Sarjana & 549 \\
\hline
\end{tabular}

Sumber: Data Profil Desa

Pada umumnya mereka menuntut ilmu lebih tinggi di Kota Malang. Jumlah alumni Strata 2 cukup besar dari tingkat pendidikan yang cukup maju diatas mencerminkan, tingkat kualitas angkatan kerja yang ada, seperti nampak pada tabel berikut.

Tabel 2. Kualitas Angkatan Kerja, Desa Candirenggo, Kec. Singosari, 2009

\begin{tabular}{clc}
\hline No & Keterangan (Kualitas Pendidikan) & Jumlah \\
\hline 1. & SD/ Sederajat & 112 \\
2. & SLTP/ Sederajat & 3.719 \\
3. & SLTA/ Sederajat & 3.307 \\
4. & Diploma & 1.207 \\
5. & Perguruan Tinggi & 2.104 \\
\hline
\end{tabular}

Sumber: Data Profil Desa

Data kesejahteraan penduduk nampak belum memadai, bilamana dibandingkan dengan tingkat kemajuan pendidikan diatas. Hal ini memerlukan penelitian lanjutan terutama dengan membandingkan subyek penelitian atau responden yang menunjukkan kolom yang sama.

Data berikut menunjukkan hal di atas. 
Tabel 3. Tingkat Kategori Kesejahteraan Penduduk Desa Candirejo Kec. Singosari, 2009

\begin{tabular}{clc}
\hline No & \multicolumn{1}{c}{ Kategori Sejahtera } & Jumlah \\
\hline 1. & Keluarga Pra Sejahtera & 521 \\
2. & Keluarga Sejahtera I & 1.811 \\
3. & Keluarga Sejahtera II & 889 \\
4. & Keluarga Sejahtera III & 627 \\
5. & Keluarga Sejahtera IV Plus & 539 \\
\hline
\end{tabular}

Sumber: Data Profil Desa

Berdasarkan tabel 3. Di atas Nampak, bahwa sebagian besar penduduk berada pada kategori Sejahtera I dan Sejahtera II. Untuk Keluarga Sejahtera III dan Sejahtera III plus juga ditemukan jumlah yang cukup besar, yaitu hamper separuh dari jumlah penduduk Kategori Sejahtera I dan Sejahtera II.

Tabel 4. Akseptor Keluarga Berencana Desa Candirejo Kec. Singosari, 2009

\begin{tabular}{clc}
\hline No & \multicolumn{1}{c}{ Kategori Sejahtera } & Jumlah \\
\hline 1. & Pasangan Usia Subur (PUS) & 2.594 \\
2. & Akseptor KB menurut Umur: & \\
& a. Kurang dari 20 tahun & 8 \\
& b. 21-30 tahun & 634 \\
& c. $31-40$ tahun & 753 \\
& d. Lebih dari 40 tahun & 1.212 \\
\hline
\end{tabular}

Sumber: Data Profil Desa

Berdasarkan tabel 4 di atas menunjukkan, bahwa Program Keluarga Berencana dimana terdapat data jumlah peserta KB pada usia produktif.

Tabel 5. Berikut menunjukkan keberhasilan Program Wajib Belajar 9 tahun. Akan tetapi jumlah siswa putus sekolah atau tidak mampu menyelesaikan pendidikan tingkat Dasar (SD) cukup memprihatinkan bilaman dibandingkan dengan keberhasilan Program Wajib Belajar 9 tahun, seperti nampak pada table berikut :

Tabel 5. Daftar Jumlah Wajib Belajar 9 Tahun Desa Candirejo Kec. Singosari, 2009

\begin{tabular}{clc}
\hline No & \multicolumn{1}{c}{ Kategori Sejahtera } & Jumlah \\
\hline 1. & Penduduk Usia 7 - 15 tahun & 3.485 \\
2. & Penduduk Usia 7 - 15 tahun yang masih sekolah & 3.136 \\
3. & Penduduk Usia 7 - 15 tahun yang tidak sekolah & 348 \\
\hline
\end{tabular}

Sumber: Data Profil Desa

\section{B. KAJIAN TEORITIS}

\section{Hubungan Sumberdaya Dan Komoditi}

Tujuan terpenting dari kebijakan harga komiditi oleh pemerintah adalah mengusahakan dan mencapai perimbangan antar pendapatan sektor pertanian dan pendapatan diluar sektor per- 
tanian (non pertanian) tidak kalah pentingnya ialah sektor industri. Apabila dikaji lebih mendalam ada pendapat, bahwa kebijaksanaan haruslah disesuaikan dengan hubungan output dan input atau keluaran dan masukan. Kebijaksanaan atas sektor juga seharusnya berbeda dengan kata lain sering berbeda. Biasanya kebijaksanaan tadi meliputi: risiko, sifat ketidakpastian (uncertainty), jenis produk/output/komoditi, faktor sosiologi dan kultur atau adat budaya serta elastisitas permintaan produk (Mubyarto, 1989).

\section{Variabel Sosial Ekonomi}

Kajian antara ekonomi desa dan ekonomi kota memerlukan pendekatan yang rasional sehubungan dengan penentuan responden (di daerah urban), yaitu keduanya ssaling mempunyai sifat ketergantungan. Berawal dari berhasilnya pembangunan ekonomi dan sosial masyarakat kiranya akan membawa pengaruh terhadap tingkat kesejahteraan masyarakat. Kesejahteraan inilah yang menjadi variable obyek yang sangat penting. Para ahli ekonomi sering melakukan pengukuran tingkat kesejteraan dilihat dari variabel ekonomi yaitu tingkat pendapatan. Pendapatan disini dimaksudkan sebagai alat ukur dengan satuan uang yang diterima dalam satuan rupiah. Variabel ekonomi yang lain besarnya pengeluaran atau belanja atau konsumsi, baik untuk pangan maupun non pangan serta tingkat produksi, investasi dan sebagainya. Sedangkan variabel sosial antara lain: tingkat pendidikan, etos kerja, jenis pekerjaan, kependudukan dan sebagainya.

\section{Teori Produksi}

Produksi secara teoritis dinyatakan sebagai proses kombinasi dan koordinasi materialmaterial dan kekuatan-kekuatan (input, faktor sumberdaya atau jasa-jasa produksi) dalam pembuatan suatu barang atau jasa (output atau produk atau komoditi). Produksi juga dapat diartikan sebagai penggunaan dan pemanfaatan sumberdaya yang mengubah suatu komoditi menjadi komoditi lainnya yang sama sekali berbeda, baik dalam penegrtian apa, dimana atau kapan komoditi tersbut dialokasikan, maupun dalam pengertian apa yang dapat dikerjakan oleh konsumen terhadap komoditi tadi. Pada intinya yang dimaksud produksi adalah sebuah proses mengkombinasikan beberapa masukan (input) menjadi sebuah keluaran (output). Output dimaksud baik berupa barang maupun jasa yang memiliki nilai guna lebih dibandingkan bentuk dasarnya, dimana nantinya akan ditawarkan untuk memenuhi kebutuhan konsumsi masyarakat. Hal selanjutnya bahwa tujuan akhir dari tiap hasil produksi secara umum adalah mendapatkan keuntungan yang maksimal bagi produsen. Istilah produksi berlaku baik untuk barang maupun jasa. Sesungguhnya agak sulit membedakan antar barang dan jasa, karena keduanya samasama dihasilkan dengan mengkombinasikan atau mengerahkan sumberdaya modal dan sumberdaya manusia.

\section{Teori Konsumsi}

Pengertian konsumsi yang sederhana adalah sebagian dari pendapatan rumah tangga (masyarakat) yang dibelanjakan yaitu dipergunakan untuk membiayai pembelian barang dan jasa serta kebutuhan pokok lainnya (basic needs) baik untuk kebutuhan sendiri maupun diberikan kepada orang lain. Perilaku konsumsi seseorang atau rumah tangga dipengarui oleh banyak variabel. Variabel-variabel tadi selalu berpengaruh (besar atau kecil) terutama terhadap kebutuhan pokok mereka. 
Secara runtut pengaruh atas keberhasilan proses pembangunan sosial ekonomi meliputi tingkat pendapatan rumah tangga, meningkatnya pertisipasi angkatan kerja, membaiknya tingkat kesehatan masyarakat, perilaku yang produktif dan rasional. Makin besar tingkat pendapatan yang diperoleh individu semakin besar pula jumlah konsumsinya atau uang yang dibelanjakan. Konsumsi yang dilakukan meliputi barang primer dan sekunder. Seluruhnya tadi akan menambah kesadaran mereka untuk mempertahankan atau bahkan meningkatnya status ekonomi keluarga. Kebutuhan pokok dapat dilihat pula dari pendekatan makro dan mikro, yaitu kebutuhan dasar secara nasional dan kebutuhan pokok dari suatu rumah tangga, sekelompok rumah tangga atau dari suatu daerah tertentu ( Sumardi, 1982) Arti lain dari kebutuhan pokok adalah sebagai suatu paket barang atau jasa yang oleh masyarakat dianggap perlu tersedia bagi setiap orang (Kian Wie, 1981). Kebutuhan ini merupakan tingkat minimal yang dapat dinikmati seseorang, dimana dapat berbeda antara masyarakat satu ke masyarakat lainnya, daerah satu ke daerah lainnya bahkan antar bangsa dari suatu Negara.

Secara rinci kebutuhan dasar manusia terdiri dari (Kian Wie, 1981):

1. Barang kebutuhan dasar seperti sandang, pangan dan papan/ pemukiman.

2. Jasa-jasa kebutuhan dasar seperti fasilitas pendidikan, kesehatan, pengangkutan, komunikasi, salurang air minum yang sehat.

3. Lapangan kerja yang produktif, dimana mampu menjamin tingkat pendapatan yang mencukupi untuk membiayai penyediaan barang-barang dan jasa-jasa kebutuhan dasar.

4. Partisipasi aktif dalam proses pengambilan keputusan yang menyangkut hidup sendiri.

Dalam tulisan Ananta (1990), dikemukakan bahwa penduduk dapat dianggap sebagai beban pembangunan dan demikian pula sebagai modal pembangunan. Anggapan yang kedua dapat diterima dengan catatan mutu sumberdaya manusia tadi ditingkatkan (optimis). Juga dikemukakan, bahwa perpindahan penduduk dari desa ke kota akan mengurangi kelebihan tenaga kerja disektor pertanian. Dengan kata lain terdapat pergeseran partisipasi tenaga kerja di sektor pertanian kini beralih ke sektor non pertanian. Dapat dikemukakan, bahwa banyak tenaga kerja yang dapat bernaung di sektor pertanian tanpa ketermapilan cukup. Bertambahnya permintaan barang-barang hasil produksi pertanian menyebabkan perubahan pola pertanian, yaitu misalnya dari pola pertanian yang subsisten menjadi pola pertanian maju.

Sejalan dengan tulisan di atas (Sukmara, 2002), menganalisis dan menemukan beberapa variabel sosial ekonomi bagi masyarakat pesisir yang mampu mempertahankan kemandirian ekonominya. Perumusan yang menarik antara lain, yaitu banyaknya penelitian-penelitian mengakibatkan perubahan spesifik dalam lingkungan hidup masyarakat pesisir dapat tercipta sesuatu hal yang positif, missal terjaminnya hak pemilikan tanah, peningkatan harapan mengenai masa depan, pemberdayaan masyarakat dan perlindungan bagi mereka.

Dalam penelitian direncakan mempunyai nilai tambah bagi proses pembangunan yang berkelanjutan pada tingkat daerah tertentu serta kelompok masyarakat (urban) tertentu. Oleh karena itu pendekatan berikut amat sesuai. Pengembangan ekonomi daerah ditinjau dari pengertian daerah secara ekonomi terdapat 3 (tiga) arti, yaitu :

1. Suatu daerah dianggap sebagai suatu ruang dimana kegiatan ekonomi terjadi dengan sifatsifat yang sama. 
2. Suatu daerah dianggap sebagai suatu ekonomi ruang dimana mempunyai satu atau beberapa kegiatan ekonomi yang dominan

3. Suatu daerah adalah suatu ekonomi ruang yang berada di bawah satu administrasi tertentu, missal satu propinsi, kabupaten, kecamatan, dan lain sebagainya.

Tujuan pembangunan sampai saat ini masih berupaya menumbuh kembangkan kegiatan ekonomi baru yang berfungsi sebagai stimulant yang mendorong pertumbuhan ekonomi di wilayah daerah tersebut sampai pada tingkat mandiri. Kiranya studi ini sejalan dengan desain penelitian yang direncanakan.

\section{Teori Investasi}

Indikasi keberhasilan suatu kegiatan ekonomi antara lain dari tingkat besaran investasi yang ditanamkan baik secara kualitatif maupun kuantitatif. Investasi diartikan sebagai pengeluaran individu yang diperoleh dari alokasi pendapatannya setelah dikurangi konsumsi. Dengan kata lain setelah individu memperoleh pendapatan kemudian melakukan aktivitas konsumsi, setelah itu sisa dari pendapatnnya ditabung atau diinvestasikan. Investasi adalah pengeluaran yang ditujukan untuk meningkatkan atau mempertahankan adanya atau tersedianya barang modal. Investasi adalah pengeluaran yang ditujukan untuk meningkatkan dan mempertahankan adanya atau tersedianya barang modal. Investasi adalah pengeluaran yang ditambahkan kepada komponen barang-barang modal yang meliputi perumahan tempat tinggal dan juga persediaan (Dornsbush dan Fischer, 1995).

Pendapat lain mengartikan investasi sebagai beberapa cara penanaman modal, baik langsung maupun tidak langsung dengan harapan pada waktunya nanti pemilik modal mendapatkan sejumlah keuntungan yang diharapkan dating dari hasil penanaman modal tersebut (Tandelilin, 2001). Selanjutnya diulas pula alasan mengapa seseorang melakukan investasi. Alasan seseorang menanamkan modalnya antara lain :

a. Untuk mendapatkan kehidupan yang lebih baik dimasa yang akan dating seseorang yang bijaksana akan berfikir upaya memperbaiki taraf hidupnya dari waktu ke waktu atau dengan kata lain menghindari penurunan tingkat pendapatnnya pada masa yang akan dating.

b. Mengurangi inflasi dengan mengambil alternative untuk berinvestasi berarti berkehendak untuk mempertahankan nilai harta kekayaannya agar tidak merosot nilainya akibat inflasi.

c. Dorongan untuk menghemat pajak. Oleh karena pemerintah memberikan fasilitas perpajakan yang sifatnya istimewa atau bersifat meringankan terutama kepada anggota masyarakat yang melakukan inverstasi pada bidang tertentu. Kebijakan fiscal ini ditujukan untuk mendorong tumbuhnya investasi dalam perekonomian (Tandelilin, 2001).

\section{METODOLOGI PENELITIAN DAN ANALISIS DATA}

\section{Daerah Penelitian}

Penelitian ini akan memfokuskan pada daerah yang memiliki karakteristik daerah urban. Daerah urban dimaksudkan sebagai daerah yang terletak diantara wilayah perkotaan dan pedesaan. Daerah yang dengan sengaja dipilih yaitu Kecamatan Singosari Kabupaten Malang. 
Berdasarkan penelitian pendahuluan dan survey lokasi ditetapkan Desa Candi Renggo sebagai lokasi penelitian. Berdasarkan data yang diperoleh desa tersebut merupakan wilayah desa yang paling luas dengan jumlah penduduk yang cukup besar. Penduduk bermata pencaharian sebagai petani, pedagang dan bekerja pula di sektor jasa serta sektor industri. Mengingat tema peneklitian yang berorientasi pada kemandirian ekonomi lokal dengan 3 (tiga) pendekatan, yaitu : penguatan bidang keuangan, bidang energy dan pangan maka penduduk Desa Candi Renggo amat memadai dipilih sebagai desa atau daerah penelitian. Daerah ini terletak dibagian barat wilayah Kecamatan Singosari. Jarak desa ke pusat pemerintahan kecamatan sekitar 1,50 kilometer. Sedangkan jarak dengan Kota Malang sekitar 12 kilometer. Pertimbangan pemilihan daerah penelitian juga didasarkan pada survey ternyata penduduk desa tersebut memberikan tanggapan yang positif, walaupun masih ada yang bersifat tertutup. Pertimbangan demikian kelak akan menjadi pertimbangan dalam memilih responden. Utamanya metode pengumpulan data dengan cara accidental sampling.

\section{Obyek Penelitian dan Teknik Sampling}

Penelitian ini bertujuan menggambarkan sekaligus menganalisis pengaruh variabel sosial ekonomi terhadap kesejahteraan responden. Sampel adalah bagian terkecil dari populasi yang mewakili populasi sebagai data empiris penelitian (Suhardjono, 2007). Menurut Sugiyono (2002) mengartikan populasi wilayah generalisasi yang terdiri atas subyek atau obyek yang mempunyai kualitas dan karakteristik tertentu yang ditetapkan untuk dipelajari dengan teliti dan kemudian ditarik kesimpulannya. Dengan kata lain populasi adalah kumpulan dari beberapa sample atau jumlah keseluruhan dari sampel.

Sampel merupakan bagian dari jumlah dan karakteristik yang dimiliki oleh populasi. Teknik pengambilan sampel dilakukan dengan cara purposive sampling, yang artinya sampel dengan sengaja diambil sebagai responden. Dalam penelitian ini ditetapkan sebesar 27 sampel. Sampel dimaksud adalah responden yang bekerja sebagai petani dan non pertanian. Secara kebetulan pengambilan data banyak mengalami kesulitan sehingga didalam menjaring responden dilakukan dengan cara accidental sampling dimana tidak semua individu atau responden dalam populasi diberi kesempatan yang sama untuk menjadi sampel dan hanya individu yang kebetulan dijumpai yang menjadi anggota sampel.

Sampel sebesar 27 responden sebenarnya ditetapkan setelah dijaring sebesar 30 sampel, yang ternyata setelah dilakukan pemeriksaan, hanya 27 responden yang memenuhi syarat kelengkapan datanya untuk dianalisis. Dari 27 responden yang sudah dilakukan penghalusan (smooting) dinyatakan valid untuk diuji. Sesuai dengan tujuan penelitian, jenis penelitian ini termasuk deskriptif-kuantitatif, yaitu memberikan gambaran sejelas mungkin tentang gejala sosial-ekonomi responden akibat perkembangan wilayah sekitarnya (urban).

\section{Analisis Data}

Untuk menjawab permasalahan dan mencapai tujuan yang ada digunakan alat analisis regresi linier berganda (multiple regression analysis) dengan dilengkapi penjelasan-penjelasan berdasarkan data pendukung terutama aspek kemandirian ekonomi ditinjau dari aspek keuangan, energy, dan pangan. Pendekatan statistic dilakukan, missal uji validitas data, reliabilitas data. Pendekatan uji statistic dipandang amat penting agar hasil penelitian memadai. Uji statistic juga 
dilakukan untuk membuktikan ada tidaknya korelasi antar variabel bebas dan variabel terikat. Dari hasil uji regresi berganda akan diketahui besarnya koefisien variabel masing-masing. Besar kecilnya koefisien akan menunjukkan kuat lemahnya hubungan variabel bebas dan terikat. Uji demikian meliputi uji regresi secara keseluruhan (Uji-F), ukuran besaran sumbangan variabel bebas (Uji-R²) dan uji regresi secara parsial (Uji-t), (Gujarati dan S. Zain, 1995).

\section{Desain Penelitian}

Berdasarkan teori dan permasalahan yang ada, rencana penelitian nampak sebagai berikut:

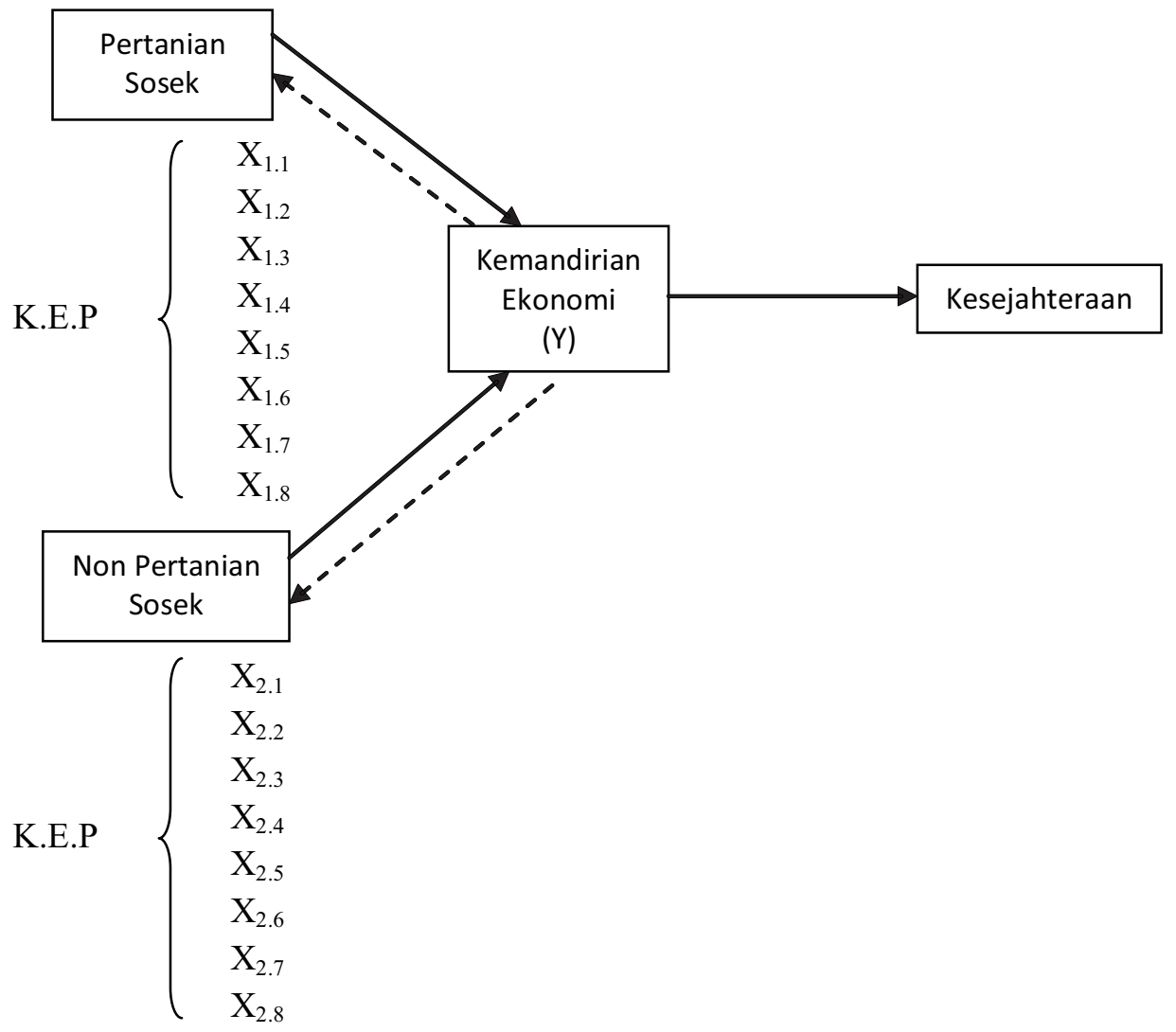

Keterangan :

\section{Pertanian/ Sosek}

adalah kelompok responden yang bekerja disektor pertanian dengan karakter sosial-ekonominya ditinjau dari Aspek Keuangan, Energi, dan Pangan (KEP).

\section{Non Pertanian/ Sosek}

adalah kelompok responden yang bekerja di sektor non pertanian dengan karakter sosialekonominya ditinjau dari aspek Keuangan-Energi dan Pangan.

\section{Kemandirian Ekonomi (Y)}

karakter responden dilihat dari besaran penghasilannya. 


\section{HASIL DAN PEMBAHASAN}

Hubungan Antara Variabel Terikat ( $Y=$ Penghasilan) dan Variabel Bebas $\left(X_{1}=\right.$ Pendidikan; $X_{2}=$ Waktu Kerja; $X_{3}=$ Masa Kerja)

Berdasarkan hasil analisis regresi dengan menggunakan data yang telah diolah (penghalusan data) (= logaritma) nampak pada persamaan berikut :

$\mathrm{Y}=49,48+0,11 \mathrm{X}_{1}-0,090 \mathrm{X}_{2}+1.1133 \mathrm{X}_{3}+\mathrm{e}$

Dari persamaan diatas berarti bahwa variabel bebas tingkat pendidikan responden, curahan waktu bekerja responden dan masa kerja responden mempunyai hubungan yang kecil. Hal ini berarti bahwa nilai determinasi sebesar 0,519 atau sebesar 51,9\%. Nilai korelasi ditemukan sebesar 0,269 saja, sedangkan variabel dilkuar model lebih banyak berpengaruh, yaitu 72,1\%. Dari hasil analisis juga menunjukkan bahwa tingkat penghasilan secara positif dipengaruhi oleh tingkat pendidikan dan variabel masa kerja, sedangkan variabel waktu kerja berpengaruh secara negative. Secara parsial variabel pendidikan merupakan variabel waktu kerja yang paling signifikan dibandingkan dengan variabel waktu kerja dan masa kerja. Hal tersebut ditunjukkan bersamasama dengan menggunakan uji F, Nampak bahwa variabel pendidikan, waktu kerja dan masa kerja berpengaruh signifikan terhadap penghasilan. Hal tersebut secara statistic ditunjukkan dengan nilai F hitung $(2,819)$ lebih besar dari F table $(2,69)$.

\section{Hubungan Antara Variabel Terikat (Y = Pengeluaran Untuk makan) dan Variabel Bebas $\left(X_{1}=\right.$ Penghasilan; $X_{2}=$ Anggota Keluarga)}

Berdasarkan analisis regresi diperoleh hasil, bahwa hubungan antara variabel terikat yaitu pengeluaran untuk makan dengan variabel bebas, yaitu tingkat pengahsilan dan jumlah anggota keluarga sangat kecil. Hal ini ditunjukkan dengan nilai dominasi sebesar 0,4011 atau sebesar 40,1\%. Dengan nilai korelasi sebesar 0,161 atau $16,1 \%$ menunjukkan bahwa pengaruh tingkat penghasilan dan jumlah anggota keluarga terhadap pengeluaran untuk makan sangat kecil. Pengeluaran untuk makan responden lebih besar dipengaruhi oleh variabel diluar model, yaitu sebesar 83,93\%. Dari hasil analisis regresi ditemukan persamaan regresinya : $\mathrm{Y}=4,182+$ $0,259 \mathrm{X}_{1}+0,41 \mathrm{X}_{2}+$ e. Persamaan tersebut mengandung arti, bahwa pengeluaran untuk makan secara positif dipengaruhi oleh tingkat penghasilan responden dan jumlah anggota keluarga responden. Dengan kata lain berarti pula semakin besar tingkat penghasilan akan menambah pengeluaran untuk makan, demikian pula semakin besar jumlah keluarga akan mengakibatkan bertambahnya pengeluaran untuk makan. Secara parsial maupun bersama-sama variabel tingkat pengahsilan berpengaruh signifikan terhadap variabel pengeluaran untuk makan. Hasil tersebut secara statistic ditunjukkan pada nilai t-hitung lebih besar dari nilai t-tabel yaitu 1,697 sedangkan nilai uji F menunjukkan angka yang lebih kecil $(2,69)$ dari F-tabel, yaitu masing-masing sebesar 2,211 dan 2,496 .

\section{Hubungan Antara Variabel Terikat ( $Y=$ Pengeluaran Non Makan) dan Variabel Bebas $\left(X_{1}\right.$ $=$ Penghasilan; $\mathbf{X}_{2}=$ Anggota Keluarga)}

Berdasarkan analisis diperoleh hasil sebagai berikut. Dengan pengeluaran non makan sebagai variabel dependent dan tingkat penghasilan serta jumlah anggota keluarga sebagai va- 
riabel independent menunjukkan hubungan yang sangat kecil. Hal tersebut ditunjukkan dengan nilai determinasi sebesar 0,532 atau sebesar 53,2\%. Dengan nilai korelasi sebesar 0,283 atau $28,3 \%$, menunjukkan bahwa pengaruh tingkat penghasilan dan jumlah anggota keluarga terhadap pengeluaran non makan sangat kecil. Berarti pula pengeluaran non makan oleh responden banyak dipengaruhi oleh variabel-variabel diluar model, yaitu sebesar 71,7\%.

Hasil analisis menemukan persamaan regresi:

$$
\mathrm{Y}=1,722+0,606 \mathrm{X}_{1}+0,016 \mathrm{X}_{2}+\mathrm{e}
$$

Hal tersebut berarti, bahwa pengeluaran non makan oleh responden secara positif dipengaruhi oleh tingkat penghasilan dan jumlah anggota kelaurga. Hal ini berarti semakin besar tingkat pendidikan dan jumlah anggota keluarga reponden akan menambah jumlah pengeluaran non makan.

Secara parsial variabel tingkat pengahsilan merupakan variabel yang paling siginifikan berpengaruh dibandingkan variabel jumlah anggota keluarga. Hal ini ditunjukkan dengan nilai thitung $(3,195)$ lebih besar dari t-tabel $(1,697)$.

Secara bersama-sama dengan menggunakan uji-F, menunjukkan bahwa variabel tingkat penghasilan dan jumlah anggota keluarga berpengaruh signifikan terhadap variabel dependent pengeluaran non makan. Seperti Nampak dengan F-hitung $(5,124)$ lebih besar dari nilai F-tabel $(2,69)$.

\section{Hubungan Antara Variabel Terikat ( $Y=$ Penghasilan) dan Variabel Bebas $\left(X_{1}=\right.$ Biaya Komunikasi; $\mathbf{X}_{2}=$ Investasi)}

Berdasarkan analisis ditemukan hasil, bahwa variabel dependent atas tingkat penghasilan dan variabel independent yang terdiri dari biaya komunikasi dan jumlah investasi menujukkan determinasi sebesar 0,636 atau 63,6\% serta korelasi sebesar 0,405 atau 40,5\%. Nilai diatas menunjukkan, bahwa variabel independent mempunyai pengaruh relative kecil, hubungan yang relative besar justru dipengaruhi dari variabel diluar model, yaitu sebesar 59,5\%.

Dari hasil analisis diperoleh persamaan regresi sebagai berikut :

$$
\mathrm{Y}=3,208+0,460 \mathrm{X}_{1}+0,090 \mathrm{X}_{2}+\mathrm{e}
$$

Persamaan diatas mempunyai arti, bahwa tingkat penghasilan secara positif dipengaruhi oleh jumlah biaya komunikasi dan investasi. Berarti pula, bahwa semakin besar biaya komunikasi dan investasi akan menambah tingkat penghasilan.

Secara parsial variabel biaya komunikasi merupakan variabel yang paling signifikan berpengaruh dibandingkan dengan investasi. Hal ini ditunjukkan dengan nilai t-hitung $(2,533)$ lebih besar dari t-tabel $(1,697)$. Secara nayata dapat dekemukakan, bahwa perilaku responden cenderung mengikuti penggunaan teknologi tinggi sebagai alat komunikasi, akan tetapi volume bisnis justru masih relative kecil dibandingkan dengan penggunaan alat tersebut, walaupun variabel ini masih lebih besar disbanding variabel investasi. Sedangkan variabel investasi masih relative kecil. Satu dan lain hal karena pengertian investasi yang masih simpang siur bagi responden.

Dalam pada itu, secara bersama-sama dengan menggunakan uji F Nampak bahwa variabel biaya komunikasi dan investasi berpengaruh signifikan terhadap tingkat penghasilan, yaitu secara statistic ditunjukkan dengan nilai F-hitung (4,575) lebih besar dari F-tabel $(2,69)$. 


\section{Hubungan Antara Variabel Terikat Yaitu Tingkat Penghasilan dan Variabel Bebas Yaitu Biaya Komunikasi, Investasi, dan Pinjaman}

Dari hasil analisis diperoleh hasil determinasi sebesar 0,732 atau 73,2\% dan hubungan korelasi sebesar 0,535 atau 53,5\%. Hasil diatas menunjukkan, bahwa variabel independent mempunyai pengaruh dan hubungan yang relative kuat dan hanya sedikit variabel dipengaruhi dari luar model, yaitu 46,5\%.

Analisis menghasilkan persamaan regresi sebagai berikut :

$$
\mathrm{Y}=8,897-0,218 \mathrm{X}_{1}+0,225 \mathrm{X}_{2}+0,053 \mathrm{X}_{3}+\mathrm{e}
$$

Hasil yang tersebut diatas mengandung arti, bahwa tingkat penghasilan secara positif dipengaruhi oleh variabel pinjaman, secara negative dipengaruhi oleh variabel biaya komunikasi. Sedangkan variabel investasi dan pinjaman menunjukkan pengaruh yang positif. Dengan kata lain semakin besar biaya komunikasi akan berpengaruh mengurangi tingkat penghasilan.

Secara parsial variabel biaya komunikasi, investasi, dan pinjaman tidak signifikan berpengaruh terhadap tingkat penghasilan. Hal tersebut Nampak dengan nilai t-hitung lebih kecil dari t-tabel.

Sedangkan dengan menggunakan uji-F secara simultan atau bersama-sama menunjukkan bahwa variabel komunikasi, investasi, dan pinjaman tidak berpengaruh signifikan terhadap tingkat penghasilan. Hasil uji tersebut Nampak pada nilai F-hitung $(0,768)$ lebih besar dari F-tabel.

\section{E. KESIMPULAN DAN REKOMENDASI}

\section{Kesimpulan}

Setelah dilakukan analisis data dengan menggunakan metode analisis deskriptif-kuantitatif terhadap berbagai faktor yang berpengaruh terhadap kemandirian ekonomi lokal, maka peneliti dapat menyimpulkan sebagai berikut :

1. Secara bersama-sama bilamana dihubungkan variabel bebas dengan variabel terikat baik variabel tingkat penghasilan, pengeluaran untuk makan ternyata mempunyai hubungan yang signifikan pada tingkat yang rendah.

2. Variabel terikat pengeluaran untuk makan, baik secara parsial maupun bersama-sama dipengaruhi secara signifikan oleh variabel tingkat penghasilan.

3. Variabel bebas tingkat penghasilan dan jumlah anggota keluarga mempunyai pengaruh yang signifikan terhadap pengeluaran non makan.

4. Variabel tingkat penghasilan secara bersama-sama dipengaruhi secara signifikan atas variabel bebas biaya komunikasi menjadi yang paling berpengaruh.

5. Hal yang lain adalah bilamana dihubungkan variabel terikat tingkat penghasilan dan variabel bebas : biaya komunikasi, investasi, dan pinjaman maka hasilnya secara nyata mempunyai hubungan yang tidak signifikan, secara bersama-sama. Demikian pula jika dianalisis secara parsial.

\section{Rekomendasi}

Berdasarkan hasil penelitian yang ditemukan, dapat diberikan saran-saran sebagai berikut:

1. Penetapan responden seharusnya memadai baik dari desa maupun penggalian oleh peneliti terutama saat survey dilaksanakan, terutama status pekerjaan responden. 
2. Survey dilakukan setelah sosialisasi memadai dan try-out secukupnya agar diperoleh data yang akurat.

3. Pemerintahan desa cukup menfasilitasi pelaksanaan survei secara administrasi sehingga respondenbebas dalam mengemukakan pendapat, dimana kadang-kadang data kurang valid lantaran menjaga perasaan dengan perangkat. Misal responden mempunyai sejumlah hutangpiutang tetapi memberikan informasi sebailknya.

4. Pada tingkat yang lebih luas suatu penelitian demikian banyak memerlukan data kualitatif agar lebih representatif misal status sosial dalam keluarga (menantu, anak, dan sebagainya) dimana kegiatan ekonominya masih menjadi satu dalam sehari-hari, namun sudah berpisah secara pemilikan.

\section{DAFTAR PUSTAKA}

Ananta, Aris. 1990. Ekonomi Sumber Daya Manusia. LDFE-UI dan PAU UI.

Anonymous. 2009. Profil Desa Candi Renggo, Kecamatan Singosari.

Anonymous. 2008. Badan Pusat Statistik. Kota Malang Dalam Angka.

Anonymous. 2007. Badan Pusat Statistik. Kabupaten Malang Dalam Angka.

Dornbusch, Fischer, Kearney, 1995, Makroekonomi : Edisi Australia.

Gujarati, Damodar. 1995. Ekonometrika Dasar. Jakarta : Erlangga.

Indriantoro, Nur dan Bambang Supomo. 1990. Metodologi Penelitian Bisnis. Yogyakarta : BPFE.

Kian Wie, Thee. 1981. Pemerataan Kemiskinan, Ketimpangan. Penerbit : Sinar Harapan.

Mubyarto, 1979. Pengantar Ekonomi Pertanian. LP3ES.

Prawirohardjono, Drs. Soetrisno. 1992. Kapita Selekta Ekonomi Indonesia. Yogayakarta : Penerbit: Andi Offset. Edisi II.

Singarimbun, Masri., dan Sofyan Effendi. 1989. Metode Penelitian Survai. Edisi Revisi, LP3ES.

Sugiyono. 2006. Metode Penelitian Kuantitatif, Kualitatif dan R \& D. bandung : Alfabeta.

Suhardjono dan Tri Budi Prayogo. 2007. Metode Penelitian Dibidang Teknik Pengairan. Universitas Brawijaya.

Sukmara, Asep dan Brian Craword. 2002. Perubahan Pengetahuan, Sikap dan Perilaku sosial Masyarakat Desa Talise Sebagai Desa Proyek Pengelolaan Sumber Daya Pesisir Berbasis Masyarakat Lokal di Sulawesi Utara. Makalah Dalam Kongres Nasional III Pengelolaan Sumber Daya Pesisir dan Lautan Indonesia.

Sumardi, Mulyanto \& Hans-Dieter Evers 1982. Kemiskinan Di Kabupaten Kutai dan kebutuhan Pokok / ed Jakarta: Diterbitkan untuk Yayasan Ilmu-Ilmu Sosial [Dibuat] Rajawali,

Tandelilin, Eduardus. 2001. Analisis Investasi dan Manajemen Portofolio. Edisi Pertama. Yogyakarta: PBFE. 